International Journal of Forensic Science \& Pathology (IJFP)

ISSN 2332-287X

\title{
Identification of Variant Alleles at CODIS STR loci in Different Populations of India
}

Tanya Chauhan

Research Article

LNJN National Institute of Criminology and Forensic Science, Sector-3, Rohini, Delhi, India.

\begin{abstract}
Two population's DNA profiling was screened for variant alleles not included within the allelic ladder provided by the manufacturer of GenePrint STR system (Promega Corporation, Madison, US). A total of 3 variant alleles were identified at 3 out of 12 STR loci tested. This study identified one variant allele at TH01 locus (allele 8.3), one at TPOX locus (allele 14) and one at vWA locus (allele 21). All these alleles have been reported previously in different populations. Allele 8.3 found at TH01 fell within the allelic range while allele 14 found at TPOX and allele 21 found at vWA fell outside the allelic range.
\end{abstract}

Keywords: Variant Alleles; CODIS STR; Forensics; TPOX; TH01; vWA.

\section{*Corresponding Author:}

Tanya Chauhan,

LNJN National Institute of Criminology and Forensic Science, Sector-3,

Rohini, Delhi, India.

E-mail: tanyachauhan@yahoo.com

Received: July 08, 2015

Accepted: September 10, 2015

Published: September 12, 2015

Citation: Tanya Chauhan (2015) Identification of Variant alleles at CODIS STR loci in Different Populations of India. Int J Forensic Sci Pathol. 3(9), 172-175. doi: http://dx.doi.org/10.19070/2332-287X-1500042

Copyright: Tanya Chauhan ${ }^{\circ} 2015$. This is an open-access article distributed under the terms of the Creative Commons Attribution License, which permits unrestricted use, distribution and reproduction in any medium, provided the original author and source are credited.

\section{Introduction}

Polymorphic Short Tandem Repeat (STR) loci have become useful tool for DNA analysis and typing for human identification and paternity testing for forensic purposes in most of the forensic laboratories in the world $[1,2]$. STR alleles of a questioned individual are designated by comparing with alleles of allelic ladder, provided by manufacturer of commercial kit [3]. Allelic ladder is the combination of alleles based on population genetic variations observed in developmental process. STR alleles of most of the DNA profiles represented with in allelic ladder are found in a small number of individuals.

For proper casework interpretations, the forensic scientists should be aware of the existence of rare alleles so that the variants can be recognised. Correctly designated alleles can sometimes greatly increased power of discrimination of STR analysis. It is, therefore, important that forensic scientists should share information on the occurrence of these variants in different populations.

India is culturally and geographically a highly diverse country. Hu- man Diversity in India is defined by 4693 different documented population groups that include 2205 major communities, 589 segments and 1900 territorial units spread across the country [4]. This diversity is due to different cultural heritage (linguistic, ethnic etc.), history of different waves of migration and impact of deep seated caste systems (or practice of strict endogamy/marriage rule). In this study, 3 variant alleles were found at 3 GenePrint STR loci, viz. TPOX, TH01 and vWA (Promega Corporation, Madison, US) during Indian population studies.

\section{Materials and Methods}

\section{Samples and DNA extraction}

A total of 244 blood samples were collected from unrelated individuals of two populations namely Rajputs and Ramgaria-Sikhs from Delhi, India. Genomic DNA from each sample was extracted by Phenol: Chloroform extraction method [5]. Whole blood sample was used as a DNA source. Extracted DNA samples were quantified by using NanoDrop spectrophotometer.

\section{PCR Amplification and STR typing}

About 2-5 ng of total DNA was used as template DNA in a total reaction volume of $25 \mu \mathrm{l}$ for each amplification process. Initially, 244 samples were screened for 12 STR loci namely CSF1PO, D16S539, D7S820, D13S317, F13A01, F13B, FESFPS, HPRTB, LPL, TPOX, TH01 and vWA using GenePrint STR system (Promega Corporation, Madison, US) and polyacrylamide gel electrophoresis.

Thermal cycling parameters were setup according to the manufacturer's protocol (Promega Corporation, Madison, US). Amplification products $(2.5 \mu \mathrm{l}$ per sample mixed with an equal volume of STR 2X loading solution) were electrophoresed at $50 \mathrm{Watt}$ for $2-4 \mathrm{~h}$ on a $40 \mathrm{cmX} 20 \mathrm{~cm}, 0.35 \mathrm{~mm}$ thick $6 \%$ denaturing polyacrylamide gel by manual GenoSequencer (Atto Corporation, Japan) with $0.5 \mathrm{X}$ TBE as gel running buffer. The bands were visualized by staining with silver stain [6]. Direct comparison between the al- 
lelic ladders and amplified samples of the same locus allowed for determination of alleles. Variant alleles were designated according to PCR product size, calculated relative to a molecular marker (pBR322 DNA/MspI digest) with Image master 1D Elite v3.01 (Amersham Biosciences, USA).

The genotype data was compiled for twelve STR markers in Excel sheets to facilitate for statistical treatment for generation of allele frequencies of the 12 STR loci. The Allele frequencies and statistical population parameters were calculated using "PowerStats" Microsoft Excel workbook template provided by Promega Corporation (http://www.promega.com/geneticidtools/).

\section{Results}

This study screened a total of 244 individuals of two different Indian populations namely Rajputs and Ramgaria-Sikhs from Delhi, for variant alleles not included in the allelic ladder provided by the manufacturer. DNA samples were initially screened for 12 STR loci by silver stain detection method. A total of 3 variant alleles were recognized at 3 STR loci viz. TPOX, TH01 and vWA and determined by a visual comparison of sample band position relative to those of known to allelic ladder. Each variant allele was confirmed by re-extraction and amplification of each locus. Allelic ladders from kit contain alleles 5-11 at TH01, 6-13 at TPOX, whereas at vWA alleles ranging from 13 to 20 (Table 1). All these variants were not included in the allelic ladder provided by GenePrint STR system amplification kit. All three variants were heterozygotes, paired with well characterized sister allele represented in allelic ladder in each case. The TH01 variant TH01 ${ }_{8.3}$ (allele 8.3) was found with $\mathrm{TH}_{0}$, allele (Figure 1) as heterozygous condition in Ramgaria-Sikh population. While variants TPOX $_{14}$ (allele 14 at TPOX) (Figure 2) and $\mathrm{vWA}_{21}$ (allele 21 at vWA) (Figure 3) were paired with TPOX $_{9}$ and $\mathrm{vWA}_{18}$ alleles, respectively in Rajput population. Variant of TPOX and vWA loci contains an allele that was larger than 4 repeats which was largest in their respective ladder (Table 2).

\section{Discussion}

The STRBase website (http:/ / www.cstl.nist.gov/biotech/strbase) lists only two variants $\mathrm{TH}_{8.3}$ and $\mathrm{TPOX}_{14}$. Alleles TH01 ${ }_{8.3}$ and TPOX $_{14}$ have been separately reported 26 and 7 times respectively in STRBase. Allele $\mathrm{vWA}_{21}$ was not reported previously in STRBase. Variant vWA 21 has previously been reported in Turks and Chinese population with a frequency of 0.004 and 0.006 , respectively [7]. While Lins et al. [8] reported this variant in Africans-Americans with a frequency of 0.002 . This variant also been reported in Germens, Moroccans, Japanese and Papuans with a frequency of $0.001,0.004,0.004$ and 0.009 , respectively [9]. Vari-

Table 1. Characteristics of STR loci that showed variant alleles.

\begin{tabular}{|c|c|c|c|c|c|}
\hline $\begin{array}{c}\text { STR } \\
\text { locus }\end{array}$ & $\begin{array}{c}\text { Chromosome } \\
\text { location }\end{array}$ & $\begin{array}{c}\text { Repeat } \\
\text { motif }\end{array}$ & $\begin{array}{c}\text { Alleles present } \\
\text { on locus }\end{array}$ & Alleles included in kit & Allele size range \\
\hline TH01 & 11p15.5 & AATG & $5-11$ & $5,6,7,8,9,9.3,10,11$ & $179-203$ \\
\hline TPOX & 2p25.1-pter & AATG & $6-13$ & $6,7,8,9,10,11,12,13$ & $224-252$ \\
\hline vWA & 12p12-pter & AGAT & $13-20$ & $13,14,15,16,17,18,19,20$ & $139-167$ \\
\hline
\end{tabular}

Figure 1. Variant $\mathrm{THO}_{8.3}$ paired with allele $\mathrm{TH}_{9}$ (sample 1) at $\mathrm{TH} 01$ locus. 1-3 are the samples amplified and A is the Allelic ladder of respective locus.

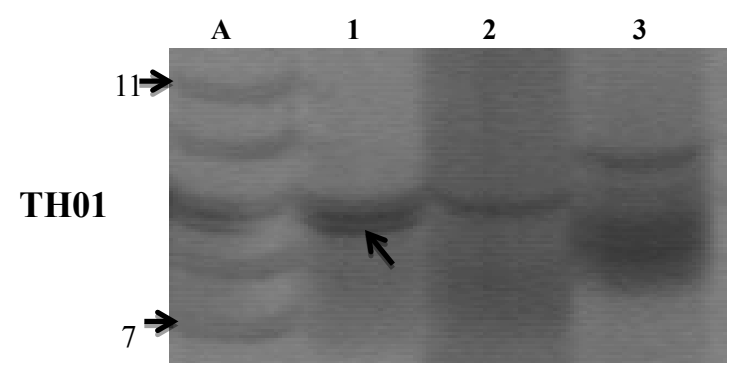

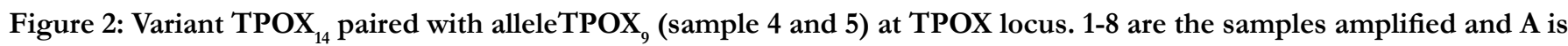
the Allelic ladder of respective locus.

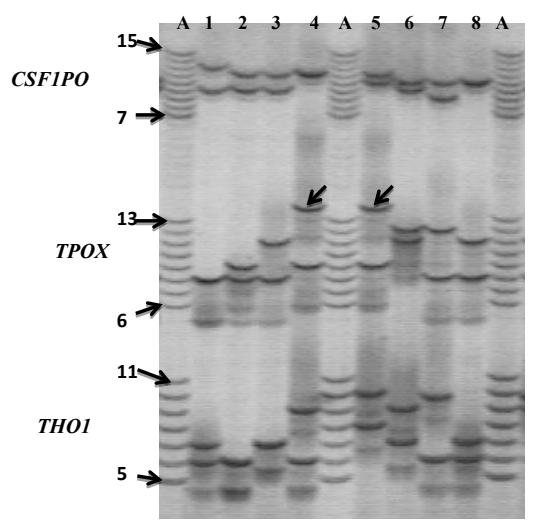


Figure 3: Variant $\mathrm{WW}_{21}$ paired with $\mathrm{vWA}_{18}$ allele (sample 5) at vWA locus. 1-8 are the samples amplified and A is the Allelic ladder of respective locus.

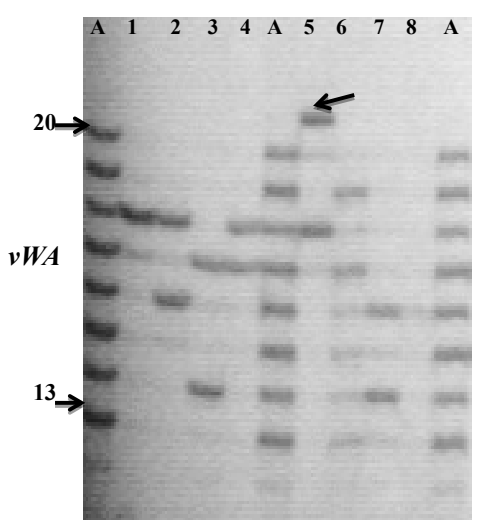

Table 2. Comparison of Allele frequencies of observed variant alleles in different populations.

\begin{tabular}{|c|c|c|c|c|c|c|c|c|c|c|}
\hline \multirow{2}{*}{$\begin{array}{l}\text { STR } \\
\text { locus }\end{array}$} & \multirow{2}{*}{$\begin{array}{l}\text { Variant al- } \\
\text { leles (VA) } \\
\text { Observed } \\
\text { (Population) }\end{array}$} & \multirow{2}{*}{$\begin{array}{l}\text { No. of VA } \\
\text { Observed in } \\
\text { Present Study }\end{array}$} & \multirow{2}{*}{$\begin{array}{c}\text { Frequency of } \\
\text { VA observed } \\
\text { in Present } \\
\text { study ( } n=\text { no. } \\
\text { of samples) }\end{array}$} & \multicolumn{3}{|c|}{$\begin{array}{c}\text { Frequency of VA observed in different } \\
\text { populations of India }\end{array}$} & \multicolumn{3}{|c|}{$\begin{array}{l}\text { Frequency of VA observed } \\
\text { in other populations }\end{array}$} & \multirow{2}{*}{\begin{tabular}{|c}
$\begin{array}{c}\text { Published } \\
\text { sequence } \\
\text { of variant } \\
\text { alleles }\end{array}$ \\
\end{tabular}} \\
\hline & & & & Frequency & Population & Reference & Frequency & Population & \begin{tabular}{|l|} 
Reference \\
\end{tabular} & \\
\hline \multirow{3}{*}{ TH01 } & \multirow{3}{*}{8.3} & \multirow{3}{*}{$\begin{array}{l}\text { 1(Ramgaria } \\
\text { Sikhs, } \\
\text { Delhi) }\end{array}$} & \multirow{3}{*}{$\begin{array}{c}0.003 \\
(\mathrm{n}=157)\end{array}$} & \multirow{3}{*}{-} & \multirow{3}{*}{ - } & \multirow{3}{*}{ - } & \multirow{3}{*}{$\begin{array}{c}0.001 \\
0.003 \\
0.05\end{array}$} & Germans & [7] & \multirow{3}{*}{$\begin{array}{c}\left(\text { AATG }_{5}\right. \\
\text { ATG } \\
(\text { AATG })_{3}\end{array}$} \\
\hline & & & & & & & & $\begin{array}{l}\text { European- } \\
\text { Americans }\end{array}$ & [12] & \\
\hline & & & & & & & & Bosnia & [13] & \\
\hline \multirow{3}{*}{ TPOX } & \multirow{3}{*}{14} & \multirow{3}{*}{$\begin{array}{l}\text { 2(Rajputs } \\
\text { Delhi) }\end{array}$} & \multirow{3}{*}{$\begin{array}{r}0.011 \\
(\mathrm{n}=87)\end{array}$} & 0.008 & $\begin{array}{c}\text { Khandayat, } \\
\text { Orissa }\end{array}$ & [16] & 0.004 & Chinese & [14] & \multirow{3}{*}{$(\text { AATG })_{14}$} \\
\hline & & & & 0.011 & $\begin{array}{l}\text { Marathas, } \\
\text { Maharashtra }\end{array}$ & [17] & 0.007 & Argentina & [15] & \\
\hline & & & & 0.008 & $\begin{array}{c}\text { Brahmins } \\
\text { Maharashtra }\end{array}$ & {$[17]$} & & & & \\
\hline \multirow{5}{*}{ vWA } & \multirow{5}{*}{21} & \multirow{5}{*}{$\begin{array}{l}\text { 1(Rajputs, } \\
\text { Delhi) }\end{array}$} & \multirow{5}{*}{$\begin{array}{c}0.006 \\
(\mathrm{n}=87)\end{array}$} & 0.01 & Rajput, U. P & [18] & $\begin{array}{l}0.004 \\
0.006\end{array}$ & $\begin{array}{l}\text { Turks } \\
\text { Chinese }\end{array}$ & {$[7]$} & \multirow{5}{*}{$\begin{array}{c}\text { TCTA } \\
(\text { TCTG })_{4} \\
(\text { TCTA })_{16} \\
\text { TCСAT } \\
\text { СТTA }\end{array}$} \\
\hline & & & & 0.016 & Reddy, A. P. & [19] & $\begin{array}{l}0.001 \\
0.009 \\
0.004 \\
0.004\end{array}$ & $\begin{array}{c}\text { Germans } \\
\text { Papuans } \\
\text { Moroccans } \\
\text { Japanese }\end{array}$ & [9] & \\
\hline & & & & 0.019 & Brahmins, A. P. & [20] & 0.002 & $\begin{array}{l}\text { Africans- } \\
\text { Americans }\end{array}$ & [8] & \\
\hline & & & & & & & $\begin{array}{l}0.002 \\
0.004 \\
0.004\end{array}$ & $\begin{array}{c}\text { Caucasians } \\
\text { Africans- } \\
\text { Americans } \\
\text { Hispanics }\end{array}$ & [10] & \\
\hline & & & & & & & 0.005 & $\begin{array}{l}\text { African- Jor- } \\
\text { danian }\end{array}$ & [11] & \\
\hline
\end{tabular}

ant $\mathrm{vWA}_{21}$ also been reported in Caucasian, African-Americans as well as Hispanics [10] with a frequency of $0.002,0.004$ and 0.004 , respectively. African-Jordanians population has a frequency 0.005 of vWA $_{21}$ variant allele [11]. Variant allele TH01 ${ }_{8.3}$ has been reported with frequency of 0.001 in German population [7]. This variant also been reported in European-Americans and Bosnia population with a frequency of 0.003 and 0.050 , respectively [12, 13]. $\operatorname{TPOX}_{14}$ has previously been reported in Chinese population with a frequency of 0.004 [14]. Berardi et al. [15] reported this variant allele in Argentina population with a frequency of 0.0071 (Table 2).

A literature search shows that variant alleles vWA ${ }_{21}$ and TPOX $_{14}$ have been reported in different Indian populations also (Table 2). Variant allele TPOX $_{14}$ has been reported in a Khandayat (Orissa), Marathas and Brahmins (Maharashtra) populations with a frequency of 0.008 .0 .11 .0 .008 respectively $[16,17]$. Variant allele
vWA has been reported in Rajputs (U. P.), Reddy and Brahmins (A. P.) populations of with a frequency of $0.010,0.016$ and 0.019 , respectively [18-20].

\section{Conclusion}

This study identified 3 unusual variant alleles at 3 loci that are not represented in commercially available allelic ladder in a database of nuclear STR profiles from India. Variant alleles TH01 and $\operatorname{TPOX}_{14}$ have been separately reported in STRBase. While allele $\mathrm{vWA}_{21}$ was not reported previously in STRBase. The variant allele $\mathrm{TH}_{01} 1_{8.3}$ was not previously reported in any population of India. Dissemination of the information will assist Forensic DNA analysis and other human identification laboratories in an Awareness of anomalies due to variants off-ladder alleles encountered during analysis. 


\section{Acknowledgements}

This study was supported by funds obtained from the Indian Ministry of Homes. Author thanks Dr. K. P. S. Kushwaha for their valuable guidance.

\section{References}

[1]. Chakraborty R, Stivers DN, Su B, Zhong Y, Budowle B (1999) The utility of short tandem repeat loci beyond human identification: Implication for development of new DNA typing system. Electrophoresis 20(8): 1682-1696.

[2]. Butler JM (2001) Forensic DNA typing: Biology and Technology behind STR markers. (2nd edtn), London Academic Press, UK.

[3]. Griffith RA, Barber MD, Johnson PE, Gillbard SM, Haywood MD, et al. (1998) New reference allelic ladder to improve allelic designation in a multiplex STR system. Int J Legal Med 111(5): 267-272.

[4]. Singh KS (1998) India's communities-People of India. National Series volume IV India, Oxford University Press, USA.

[5]. Shambrook J, Accallum P, Russell D (2001) Molecular cloning: A Laboratory manual. (3rd edtn), Cold Spring Harbour Laboratory Press, New York.

[6]. Bassam BJ, Caetaro-Anolles G, Gresshoff PM (1991) Fast and sensitive silver staining of DNA in polyacrylamide gels. Anal Biochem 196(1): 80-83.

[7]. Brinkmann B, Sajantila A, Goedde HW, Matsumoto H, Kand N, et al. (1996) Population Genetic comparisons among eight population using allele frequencies and sequence data from three microsatellite loci. Eur J Hum Genet 4(3): 175-182.

[8]. Lins AM, Micka KA, Sprecher CJ, Taylor JA, Bacher JW, et al. (1998) Development and population study of an eight-locus Short Tandem Repeat (STR) multiplex system. J Forensic Sci 43(6): 1168-1180.

[9]. Brinkmann B, Junge A, Meyer E, Weigand P (1998) Population Genetic Diversity in relation to microsatellite heterogeneity. Hum Mutat 11(2): 135144 .

[10]. Butler JM, Schoske R, Vallone PM, Redman JW, Kline MC (2003) Allele
Frequencies of 15 autosomal STR loci on U. S. Caucasian, African and Hispanic populations. J Forensic Sci 48(4): 908-911.

[11]. Yasin SR, Hamad MM, Elkarmi AZ, Jaran AS (2005) African Jordanian population genetic database on fifteen Short Tandem Repeat Genetic loci. Croat Med J 46(4): 587-592.

[12]. Budowle B, Moretti TR, Baumstark AL, Defenbaugh DA, Keys KM (1999) Population data on thirteen CODIS core STR loci in African Americans, US Caucasians Hispanics, Bahamians, Jamaicans and Trinidadians. J Forensic Sci 44(6): 1277-1286.

[13]. Huel RML, Basic L, Todorovie K, Smajlovic L, Eminovic I, et al. (2007) Variant alleles, Tri-allelic patterns and Point mutations observed in nuclear Short Tandem Repeat typing of populations in Bosnia and Serbia. Croat Med J 48(4): 494-502.

[14]. Huang NE, Schumm JW, Budowle B (1995) Chinese population data on 3 tetrameric STR loci (HumTH01, TPOX, CSF1PO) derived using multiplex PCR and manual typing. Forensic Sci Int 71: 131-136.

[15]. Berardi G, Toscanini U, Raimondi E (2003) STR data for Powerplex 16 system from Buenos Aires population, Argentina. Forensic Sci Int 134(2-3): 222-224.

[16]. Sahoo S, Kashyap VK (2002) Allele frequency data for powerplex 16 loci in four major populations of Orissa, India. J Forensic Sci 47(4): 912-915.

[17]. Gaikwad S, Kashyap VK (2002) Polymorphism at fifteen hypervariable microsatellite loci in four populations of Maharashtra, India. Forensic Sci Int 126(3): 267-271.

[18]. Tandon M, Trivedi R, Kashyap VK (2002) Genomic diversity at 15 fluorescent labeled short tandem repeat loci in few important populations of State of Uttar Pradesh, India. Forensic Sci Int 128(3): 190-195.

[19]. Kashyap VK, Ashma R, Gaikwad S, Sarkar BN, Trivedi R (2004) Deciphering diversity in populations of various linguistic and ethnic affiliations of different geographical regions of India: analysis based on 15 microsatellite markers. J Genet 83(1): 49-63.

[20]. Reddy BM, Naidu VM, Madhavi VK, Thangaraj K, Langstieh BT, et al. (2005) STR data for the Amp FISTR Profiler Plus loci among 27 populations of different social hierarchy from southern part of Andhra Pradesh, India. Forensic Sci Int 149(1): 81-97. 